November 2016

\title{
Secrecy, Democracy and War: A Review
}

Brian Martin

University of Wollongong, Australia

Follow this and additional works at: https://scholarworks.sjsu.edu/secrecyandsociety

Part of the History Commons, Law Commons, Political Science Commons, and the Public Affairs, Public Policy and Public Administration Commons

\section{Recommended Citation}

Martin, Brian. 2016. "Secrecy, Democracy and War: A Review." Secrecy and Society 1(1). https://doi.org/10.31979/2377-6188.2016.010110 https://scholarworks.sjsu.edu/ secrecyandsociety/vol1/iss1/10

This Book Review is brought to you for free and open access by the School of Information at SJSU ScholarWorks. It has been accepted for inclusion in Secrecy and Society by an authorized administrator of SJSU ScholarWorks. For more information, please contact scholarworks@sjsu.edu.

\section{(c) (1)}

This work is licensed under a Creative Commons Attribution 4.0 License. 


\section{Secrecy, Democracy and War: A Review}

\section{Keywords}

Scott Horton, Lords of Secrecy, national security, review, secrecy, war 


\section{Secrecy, Democracy and War: A Review Brian Martin}

Scott Horton's book Lords of Secrecy: The National Security Elite and America's Stealth Warfare is a powerful indictment of secrecy. His focus is on the US national security state and decisions about warmaking. Horton sees secrecy as the most important tool wielded by what he calls "national security elites" in aggrandizing power. The situation is dire. The normal checks on unrestrained power - including congressional scrutiny and media coverage - are failing. Horton sees whistleblowers as the last hope for transparency, yet US national security whistleblowers are under attack like never before.

Horton's argument about war-making is sophisticated and fascinating. He is careful to say that he is not against war, nor necessarily against US military interventions in other countries. His concern is that decisions about such matters should only be made after some form of public discussion, which might involve congressional hearings, coverage in the mass media, and involvement by citizens through being informed and being able to discuss options.

He notes three methods used by the US government to reduce opposition to wars: ending the draft; developing technologies that 
minimize casualties; and using military contractors, given that members of the public seem less concerned about deaths of contractors than of US soldiers. These methods have reduced public interest in discussions about war-fighting. Horton does not engage with the decisions in these matters - for example, he does not pass judgment about military contractors because his concern is about democratic process. He thinks these issues should be discussed widely. One of the reasons they are not so discussed is government secrecy; indeed, according to Horton, it is the key factor.

To ground his analysis, Horton appeals to the concept of "knowledge-based democracy," in which citizens have access to information necessary to make informed contributions to debates about important matters. The precedent for knowledge-based democracy was ancient Athens, in which matters of state were openly debated in forums allowing the participation of all citizens, restricted to free men to be sure, but providing a model for citizen participation seldom matched since.

Following Aristotle, Horton contrasts knowledge-based democracy with tyranny and sham democracy. In a democracy, the affairs of state are public while the affairs of individuals are private, while in a dictatorship this is reversed: "Fearing ordinary citizens, a tyrant routinely intrudes into their private affairs to detect hostility" (Horton, 2015, p. 43). The relevance to today's governments is obvious: national security is 
enveloped in secrecy, and citizens are spied upon, with terrorism the current pretext. Previously, communism was the threat used to justify surveillance. It seems that national security has become a permanent threat to democracy, whereas previously this mainly occurred during major wars. Horton's argument is that secrecy is central to this state of affairs.

The US national security system is built around the organizational form called bureaucracy, whose key characteristics are hierarchy and a division of labor. Horton sees a tight link between bureaucracy and secrecy, which is loved by bureaucrats, who sometimes use it legitimately but in other cases illegitimately, for instance to hide incompetence, mistakes, corruption, and anything embarrassing. Horton provides the example of "Frances," who rose in the CIA while making blunders and being involved in torture; secrecy protected her and allowed her career to flourish.

With this background, Horton analyzes the rise of the US national security state, showing how its resultant form clashes with views about war and public debate from ancient Athens. Horton says that in setting up the national security state in the aftermath of World War II, President Harry Truman, Secretary of State Dean Acheson, and other key figures saw that secrecy needed to be controlled, because the point of the 
military was to protect democratic values. Many would see this as a rather idealistic picture, but in any case Truman and others did build into the system an oversight mechanism operating through the US Congress. Horton says, "They did not foresee that Congress would be no match for intelligence services commanding enormous budgets and vast staffs and, most importantly, adroitly manipulating secrecy." (p. 100).

Horton attributes most of the problems to secrecy; that is, after all, the theme of his book. But this may overshadow other driving forces, such as state aggrandizement, bureaucratic hierarchy, and the corruptions of power. Is secrecy the lynchpin of the problems with the US national security apparatus, or is it simply one tool or feature of many? Whatever the answer, there is no doubt that secrecy plays a key role in the US war system. Horton notes that there is less public outrage when the soldiers who are killed or maimed are volunteers or contractors. In previous wars, the dead were publicly honored, but now there are no photos and no letters from state officials to survivors. Official records are not kept of deaths and injuries of contractors.

Horton gives special attention to drones, which are emblematic of warfare conducted with maximum secrecy. He says that national security elites like drones precisely because they operate in secrecy and are a zero-casualty technology, in the sense that there are no casualties 
involving US personnel, though plenty among the "enemy." The secrecy involved is also one-sided: people in target countries know a lot about drone strikes through personal experience at the receiving end and through local and national publicity. It is mainly people in the US who remain in the dark about drone strikes and about their possible counterproductive consequences, for example building solidarity between radicals and the population. Horton also notes a double standard involved: if it is okay for the US military to assassinate opponents using drones, then is it acceptable for other governments to use drones for assassination?

The implication is that secrecy-driven war-fighting strategies may end up being counterproductive in the long term. That is something that has been noted by many observers, for example with the CIA supporting Afghan insurgents against the Soviet 1979 invasion, and these insurgents morphing into the now-demonized Taliban. The next question is whether this is part of a self-perpetuating process. Drone strikes, especially when civilians are killed, can antagonize the population, swelling the numbers of insurgents, thus justifying further strikes, in a cycle of perpetual war that provides a convenient justification for sustaining the military-industrial complex and its associated secrecy. 
Given the failure of the normal controls on secret war-making, namely Congress and the mass media, Horton sees one remaining remedy: whistleblowers who expose information within the national security system that actually should be part of public debates. These whistleblowers are "the last and best hope to check antidemocratic abuses of secrecy" (p. 133). In this context, it is not surprising that the government has waged what Horton calls a "war on whistleblowers." Not only do whistleblower laws in practice provide little or no protection against reprisals - they may give only an illusion of protection - but the US government under Obama has mounted an unprecedented number of prosecutions of national security whistleblowers using the otherwise littleused and totally inappropriate Espionage Act. Horton does not blame Obama, saying the increased use of the act is due to the increased power of the national security elites.

In a chapter titled "Drowning in secrets," Horton addresses three areas where he believes secrets are justified: sensitive weapons system, signals intelligence, and the identity of covert operatives. In two areas, he says secrecy is never justifiable: laws, and retrospective classification of publicly available material. He notes that the official rules for classified material are reasonable, but they are not followed, with a strong 
tendency towards overclassification. The result is a rapidly expanding volume of official secrets.

\section{Assessment}

Lords of Secrecy is an important contribution in several respects. It documents with clarity the crucial role that secrecy plays in the US national security system, and the failure of controls over abuses within the system. Horton embeds his critique within a picture of knowledgebased democracy, thus giving a rationale for opposing secrecy that links with widely supported ideals in the US. Horton provides a diagnosis of measures to control excess secrecy, with the perhaps surprising conclusion that "whistleblowers alone provide a meaningful safety brake on dangerously overextended secrecy claims" (p. 200). Lords of Secrecy can be read as a call to take secrecy more seriously when questioning and challenging US war-fighting.

One limitation of the book is that there is little comparison with practices and developments in other countries. In many places, secrecy is far greater than in the US, where the First Amendment and freedom-ofinformation procedures can be used as tools to expose government operations. In Britain, for example, the national security apparatus operates in extreme secrecy. After World War II, an entire network of 
underground enclaves was developed so the government could survive a nuclear attack and defend itself against its own citizens, an operation only exposed by dedicated investigators (Laurie, 1970). It is implausible that in the US such an extensive network of bunkers and preparations against rebellion could remain secret. In another example, in 2006 the British government intervened to stop the Serious Fraud Office from continuing a major investigation of arms manufacturer BAE's alleged bribes paid to officials in Saudi Arabia, on the grounds that the investigation would undermine intelligence connections (Leigh and Evans, 2006).

In Australia, freedom-of-information requests about extraordinary rendition, Guantanamo Bay, and Australian government knowledge of torture in the US prison camp were stalled for years by various government departments (Brooks, 2015). FOI requests in the US for the same material led to the release of thousands of documents. One difference is that in the US it is possible to sue to obtain documents refused under the FOI Act, whereas a similarly effective mechanism does not exist in Australia.

It may be asked, is secrecy actually so central to the US national security system and, if so, does this mean it is even more central to security systems in some other countries? In some countries, such as Sweden, access to government documents is far easier than in the US. 
Yet the Swedish government monitors telecommunications and Sweden is the world's largest exporter of arms on a per-capita basis. It would not be appropriate to draw any strong conclusions from these observations. The point worth noting is that analysis of the role of secrecy in national security systems in a variety of countries would be worthwhile, potentially offering deeper insight into what is typical and what is exceptional about the US case. That the US military is by far the most powerful in the world is probably relevant, as is the subservient role of the US mass media, but further investigation is warranted.

For controlling the excesses of the national security establishment and enabling something closer to knowledge-based democracy, Horton looks to Congress, the mass media, and finally whistleblowers. There is one important omission: social movements. The labor, feminist, antiracist, environmental, and peace movements - among others - have made a huge difference to the operation of US politics, with policies and practices being transformed over time. The movement against nuclear weapons can be credited with restraining governments from nuclear war (Wittner, 1993-2003). Many social movements have pushed for greater participation by citizens in decision-making; that is a central theme in the global justice movement. 
In this context, there are challenges to the national security establishment from peace groups, anti-surveillance campaigners, free speech advocates, and various groups critical of abuses of state power. Whistleblowing will have little effect unless there is a public receptive to disclosures; social movements are crucial to fostering public awareness of social issues and the willingness and capacity to take action for change.

Lords of Secrecy is a notable achievement, worth reading for its informed discussions of US national security in the context of knowledgebased democracy, with excessive government secrecy fingered as the key factor enabling the undermining of democratic values. The task for scholars is to broaden the analysis to other countries; the task for activists is to contribute to a strategy against excessive secrecy and the unaccountable power it protects.

\section{References}

Brooks, Aloysia. 2016. Freedom of information Cases. Accessed June 8, 2016. http://www.aloysiabrooks.com/foi-lawsuit/

Horton, Scott. 2015. Lords of Secrecy: The National Security Elite and America's Stealth Warfare. New York: Nation Books.

Laurie, Peter. 1970. Beneath the City Streets. London: Penguin.

Leigh, David and Rob Evans. 2006, December 15. "'National Interest' Halts Arms Corruption Inquiry." The Guardian. Accessed June 8, 
2016.

https://www.theguardian.com/uk/2006/dec/15/saudiarabia.armstrad e

Wittner, Lawrence S. 1993-2003. The Struggle Against the Bomb.

Three volumes. Stanford, CA: Stanford University Press. 